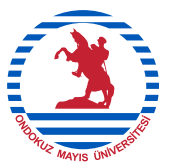

\title{
Does Fear Of Covid-19 Affect Eating Disorder and Social Appearance Anxiety? A Descriptive Research With Young Female University Students in Turkey
}

\author{
Covıd-19 Korkusu Yeme Bozukluğunu ve Sosyal \\ Görünüş Kaygısını Etkiler mi? Türkiye'deki Genç Kız \\ Üniversite Öğrencileri ile Tanımlayıcı Вiг Агaştırma
}

Hacer UNVER ${ }^{1}$

\footnotetext{
1 Inonu University, Faculty of Health Sciences, Department of Midwifery, Malatya, Turkey • hacer.unver@inonu.edu.tr• ORCID > 0000-0002-5406-4566
}

Makale Bilgisi / Article Information

Makale Türü / Article Types: Araştırma Makalesi / Research Article

Geliş Tarihi / Received: 17 Eylül / September 2021

Kabul Tarihi / Accepted: 22 Kasım / November 2021

Yil / Year: 2021 | Cilt - Volume: 6 | Sayı - Issue: 3 | Sayfa / Pages: 477-490

Atıf/Cite as: Unver, K. "Does Fear Of Covid-19 Affect Eating Disorder And Social Appearance Anxiety? A Descriptive Research With Young Female University Students in Turkey - Covid-19 Korkusu Yeme Bozukluğunu ve Sosyal Görünüş Kaygısını Etkiler Mi? Türkiye'deki Genç Kız Üniversite Öğrencileri Ile Tanımlayıcı Bir Araştırma”. Samsun Sağlık Bilimleri Dergisi- Journal of Samsun Health Sciences 6(3), Aralık 2021: 477-490. https://doi.org/10.47115/jshs.997108

\section{Sorumlu Yazar: Hacer UNVER}

Copyright @ Published by Ondokuz Mayıs Üniversitesi, Sağlık Bilimleri Fakültesi - Ondokuz Mayıs University, Faculty of Health Sciences, Samsun, Turkey. All rights reserved. 


\title{
DOES FEAR OF COVID-19 AFFECT EATING DISORDER AND SOCIAL APPEARANCE ANXIETY? A DESCRIPTIVE RESEARCH WITH YOUNG FEMALE UNIVERSITY STUDENTS IN TURKEY
}

\begin{abstract}
:
Aim: This research was conducted to determine the effect of fear of COVID-19 on eating disorder and social appearance anxiety in young female students.

Method: The sample of the descriptive type of research consists of 416 female students who are taught at two faculties of the public university located in eastern Turkey. The research data was collected using the demographics characteristics form, the fear of COVID-19 scale, eating disorder examination questionnaire, and social appearance anxiety scale.

Results: In the study, it was determined that the young females had a near-moderate level (18.51 \pm 6.86$)$ of COVID-19 fear. Besides, a significant positive relationship was found between COVID-19 fear and social appearance anxiety and eating disorder total, and sub-dimensions (weight concern, eating concern, shape concern, restraint, binge eating) mean scores ( $\mathrm{r}=.388, \mathrm{r}=.192, \mathrm{r}=.200, \mathrm{r}=.192$, $\mathrm{r}=.172, \mathrm{r}=.128, \mathrm{r}=.289 ; \mathrm{p}<.01)$. Regression analysis showed that COVID-19 fear in young females was $15 \%$ effective in explaining social appearance anxiety $(\mathrm{p}<001)$.

Conclusion and Suggestions: As a result of the findings obtained from the study, it is seen that there is a significant relationship between COVID-19 fear level and social appearance anxiety and eating disorder, and coronavirus fear has a significant effect on social appearance anxiety. It is thought that interventions for fear of COVID-19 in young females could affect eating disorders and social appearance anxiety.
\end{abstract}

Keywords: Anxiety; COVID-19; Eating disorder; Social appearance

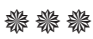

\section{COVID-19 KORKUSU YEME BOZUKLUĞUNU VE SOSYAL GÖRÜNÜŞ KAYGISINI ETKILER MI? TÜRKIYE'DEKI GENÇ KIZ ÜNIVERSITE ÖĞRENCILERI ILE TANIMLAYICI BIR ARAŞTIRMA}

ÖZ:

Amaç: Bu araştırma genç kızlarda COVID-19’a yönelik korkunun yeme bozukluğu ve sosyal görünüş kaygısına etkisini saptamak amacıyla yapıldı. 
Yöntem: Tanımlayıcı tipte yapılan araştırmanın örneklemini, Türkiye’nin doğusunda bulunan bir kamu üniversitesinin iki fakültesinde öğrenimleri devam eden 416 kız öğrenci oluşturdu. Veriler kişisel tanıtım formu, COVID-19 korkusu ölçeği, yeme bozukluğu belirleme ölçeği ve sosyal görünüş kaygısı ölçeği kullanılarak ile topland.

Bulgular: Araştırmada genç kızların ortalamaya yakın düzeyde (18.51 \pm 6.86$)$ COVID-19 korkusu yaşadığı saptandı. Araştırmada COVİD-19 korkusuyla sosyal görünüș kaygısı, yeme bozukluğu toplam ve alt boyut (kilo kaygısı, yeme kayg1sı, şekil kaygısı, kısıtlama, tıkınırcasına yeme) puan ortalamaları arasında pozitif yönde anlamlı ilişki saptandı (sırasıyla $\mathrm{r}=.388, \mathrm{r}=.192, \mathrm{r}=.200, \mathrm{r}=.192, \mathrm{r}=$ $.172, \mathrm{r}=.128, \mathrm{r}=.289 ; \mathrm{p}<.01$, Table 2.). Yapılan regresyon analizi genç kızlardaki COVİD-19 korkusunun sosyal görünüş kaygısını açıklamada \%15 oranında etkili olduğu gösterdi $(\mathrm{p}<.001)$.

Sonuç ve Önerileri: Araştırmadan elde edilen bulgular sonucunda COVID-19 korku düzeyi ile sosyal görünüş kaygısı ve yeme bozukluğu arasında önemli ilişki olduğu görülmektedir. Genç kızlarda COVID-19 korkusuna yönelik müdahalelerin yeme bozuklukları ve sosyal görünüş kaygıları üzerinde etkili olabileceği düşünülmektedir.

Anahtar Kelimeler: Anksiyete; COVID-19; Sosyal Görünüş Kaygısı; Yeme Bozuklŭgu

\section{INTRODUCTION}

Coronavirus, which first appeared in 2019 and was seen in China, spread as a global health crisis worldwide in a short period of three months and affected Turkey after March 11, 2020 (Ministry of Health of Turkey, 2020b; WHO, 2020e). The COVID-19 pandemic exposes individuals to loss, uncertainty, isolation, financial difficulties, insecurity, inability to access social support, and poses a risk to individuals in terms of mental health (Ministry of Health of Turkey, 2020b; Sarıcam et al., 2014). Additionally, with the increasing mortality and morbidity rates in the pandemic, an increase in psychological problems such as panic, stress, fear, and depression started to increase (Ahorsu et al., 2020; Akbas \& Dursun, 2020; Craig et al., 2020; Ercan, 2020; Sarı \& Dağ, 2009; Steinberg et al., 2016; Taylor et al., 2020).

The quarantine at home, carried out within the scope of COVID-19 measures, causes individuals to stay away from their daily routine and live a sedentary life (Kartal \& Kayıksız, 2020). This situation leads to an increase in the desire to con- 
sume food, a change in eating behavior, and eating disorders (Kartal \& Kayıksız, 2020; Labrague et al., 2020). It was reported that individuals might feel the need to eat and have eating disorders even when they are not hungry to control their negative emotions, feel happy and safe in situations where uncertainty and threat perception is high (Serin \& Sanler, 2018). However, the prevalence of eating disorders in our country increased in the last 25 years, and it was observed that most of the eating disorders occur before the age of 25 (Akdevelioglu \& Yorusun, 2019; Cakıroglu et al., 2020). It is stated that the prevalence of eating disorders is high during the university years when ready-made food consumption, fast food, solid food, and night eating habits are common (Cakıroglu et al., 2020). It is known that young people who gain weight due to unhealthy eating experience weight anxiety, which will bring dissatisfaction with body perception (Oruclular, 2013). This anxiety about physical appearance in young people causes social appearance anxiety (Dogan, 2010). It is stated that this anxiety experienced in young people leads to negative social, professional, and primarily academic effects (Simsir et al., 2019). However, young people with positive body perception behave more autonomously, take more responsibility, and develop healthier family and professional relationships (Eksi et al., 2016). Considering that they did not start their profession and the vast majority of them did not establish their families, it is predicted that young university students play a crucial role in public health in the future.

Long mandatory school holidays and home isolation to counter the threat of the COVID-19 epidemic forced many young people (at least 3,408.815 young people in the Turkey to stay at home, causing problems such as boredom, spending more time on the internet, watching TV for longer, being less active, eating more, and increasing weight gain (Commission on Higher Education, 2020; Jiao et al., 2020). The fear of COVID-19 and the lack of activity caused by the epidemic negatively affect the youth, both mentally and physically (Wenjun et al., 2020). It is thought that social appearance anxiety and eating disorder may be important for young girls in this process. Despite the evidence suggesting fear experienced during the epidemic, no previous studies investigating the effect of fear on eating disorder and social appearance anxiety were found (Wenjun et al., 2020). For this reason, this study was conducted to determine the effect of fear of COVID-19 on eating disorder and social appearance anxiety in young females in the coronavirus pandemic.

\section{MATERIALS AND METHODS}

The descriptive-type research was carried out in two faculties of the university located in eastern Turkey. The research population was formed by young females in the two faculties of the specified university (N:2590). When the power analysis was done, the sample size was calculated to be at least 335 , with a $5 \%$ error margin and 
95\% ability to represent the universe. The research was completed with a total of 416 young female participants. The publicly available statistical software OpenEpi was used to calculate the sample size.

\section{Inclusion criteria}

- $\quad$ Aged between18-25

- Open to communication and cooperation

- Continuing education as a student

- No psychiatric illness

- $\quad$ Not using any psychiatric medication

Data Collection Tools: The research data were collected through Google Forms prepared by the researchers. Data were collected using "Personal Information Form", "The Fear of COVID-19 Scale (FCV-19S)", "The Eating Disorder Examination Questionnaire (EDE-Q)" and "Social Appearance Anxiety Scale (SAAS)". In addition to descriptive statistical analyzes, correlation and regression analysis were used to analyze the data.

Personal Information Form: The form contains a total of 7 questions about the socio-demographic characteristics of young females, such as age, gender, economic status, and education.

The Fear of COVID-19 Scale (FCV-19S): The adaptation, validity, and reliability of FCV-19S, developed by Ahorsu et al. (2020), to Turkish were made by Satic1 et al. (2020). The applicable age range of the scale is comprehensive, and it can be used on university students and adults. All items of the scale consisting of one dimension and 7 questions are scored positively. The questions were scored between 1-5 (1- Strongly disagree, 5-Strongly agree) using a 5-point Likert type scaling. There is no reverse coded item on the scale. Scores between 7 and 35 can be achieved on the scale. A high score obtained from the scale means experiencing high levels of coronavirus fear. In the Turkish validity and reliability study of the scale, the Cronbach's alpha value was found as $(\alpha=.82)$. In this study, the Cronbach's alpha value was found as $(\alpha=.88)$.

The Eating Disorder Examination Questionnaire (EDE-Q): This scale is the self-report form of the eating disorders assessment interview (Fairburn \& Cooper, 1993). The purpose of the scale is to measure and diagnose eating disorders. It con- 
sists of 33 questions and five subscales of restriction items reflecting the severity of eating disorder psychopathology (items 1, 2, 3, 4, and 5), 6 items of binge eating in which specific behaviors related to eating disorders are evaluated, shape concerns (items 6, 8, 23, 10, 26, 27, 28, and 11), eating concerns (items 7, 9, 19, 21, and 20), and weight-related concerns $(22,24,8,25$, and 12$)$. The subscale and total score ranges between 0 and 6 . A high score indicates the high level of the pathology. The Turkish validity and reliability study of the scale was performed by Yücel et al. (2011). The Cronbach's alpha value of the scale was found to be $(\alpha=.93)$ (Yucel et al., 2011). In this study, the Cronbach's alpha value was found as $(\alpha=.88)$.

Social Appearance Anxiety Scale (SAAS): It is a self-report style scale developed by Hart et al. (2008) to measure the emotional, cognitive, and behavioral anxieties experienced by the individual regarding his appearance. SAAS is a 5-point Likert type scale consisting of 16 items. The answers to the scale items are selected among the options of (1) Strongly Disagree, (2) Disagree, (3) Somewhat Agree, (4) Agree, (5) Strongly Agree. Only item 1 of the scale is reverse-coded. High scores from SAAS, which measures social appearance anxiety in one dimension, indicate that appearance anxiety is high. The Turkish adaptation of the scale was conducted by Dogan (2010) for its validity and reliability study. The Cronbach's alpha internal consistency coefficient for SAAS was found to be 93 (Dogan 2010). In this study, the Cronbach's alpha value was found as $(\alpha=.95)$.

Data Analysis: The research data were analyzed with SPSS 26.0 software for Windows (SPSS, Chicago, IL, USA). Besides descriptive analysis methods (number, percentage, mean, and standard deviation), advanced analysis methods (correlation and linear regression) were used in statistical analysis.

\section{RESULTS}

The distribution of some of the young females' demographic characteristics who participated in the study is given in Table 1. It was found that the mean age of young females is $20.12 \pm 1.56$. $38.5 \%$ of the participants are studying at the midwifery department, $50.2 \%$ are at the 2 nd grade, $55.3 \%$ of them have equal income and spending, $92.8 \%$ do not have chronic diseases, $52.6 \%$ spend the longest period of their lives in a district, $92.8 \%$ of them do not have a chronic disease and $91.3 \%$ do not use medication regularly, $62.5 \%$ of them were found to be in the normal weight range. (Table 1). 
Table 1. The distribution of some of the characteristics of the participants $(\mathrm{n}=416)$

\begin{tabular}{|c|c|c|}
\hline Characteristics & $\mathbf{n}$ & $\%$ \\
\hline \multicolumn{3}{|l|}{ Department of education } \\
\hline Midwifery & 160 & 38.5 \\
\hline Nursing & 137 & 32.9 \\
\hline Child Development & 84 & 20.2 \\
\hline Audiology & 11 & 2.6 \\
\hline $\begin{array}{l}\text { Physical therapy and rehabili- } \\
\text { tation }\end{array}$ & 24 & 5.8 \\
\hline \multicolumn{3}{|l|}{ Grade n (\%) } \\
\hline 1st. year & 121 & 29.1 \\
\hline 2nd year & 209 & 50.2 \\
\hline 3rd year & 47 & 11.3 \\
\hline 4th year & 39 & 9.4 \\
\hline \multicolumn{3}{|l|}{ Income status n (\%) } \\
\hline Income more than expenses & 39 & 9.4 \\
\hline Income equal to expenses & 230 & 55.3 \\
\hline Income less than expenses & 147 & 35.3 \\
\hline \multicolumn{3}{|l|}{ The longest place in life } \\
\hline Province & 197 & 47.4 \\
\hline Town - Village & 219 & 52.6 \\
\hline \multicolumn{3}{|l|}{ Presence of chronic illness } \\
\hline Yes & 30 & 7.2 \\
\hline No & 386 & 92.8 \\
\hline \multicolumn{3}{|l|}{ Regular medication use } \\
\hline Yes & 36 & 8,7 \\
\hline No & 380 & 91.3 \\
\hline \multicolumn{3}{|l|}{ BMI } \\
\hline Underweight $(<18.5)$ & 85 & 20.4 \\
\hline Normal (18.5-24.9) & 260 & 62.5 \\
\hline Slightly fat (25-29.9) & 56 & 13.5 \\
\hline First degree obese (30-34.9) & 15 & 3.6 \\
\hline
\end{tabular}

BMI: Body mass index

Table 2 shows the relationship between FCV-19S level and SAAS, EDE-Q total score, and subscales in young females. A strong positive correlation was observed between FCV-19S level, and SAAS mean score, EDE-Q, WC, EC, SC, R, and BE $(\mathrm{p}<0.01)$. As the fear of COVID-19 increased in young females, the mean scores of SAAS, EDE-Q, WC, EC, SC, R, and BE increased.

A strong positive relationship was found between the SAAS mean score and the 
means of the EDE-Q total WC, EC, SC, R, and BE subscales score $(\mathrm{p}<0.01)$. As the level of social appearance anxiety increased in young girls, it was seen that eating disorder, weight concern, eating concern, shape concern, restraint, and binge eating levels increased significantly.

It was determined that there was a strong positive relationship between the mean EDE-Q total score and the mean scores of the WC, EC, SC, R, and BE subscales $(\mathrm{p}<0.01)$. As the eating disorder increased in young females, a significant increase was determined in the levels of weight concern, eating concern, shape concern, restraint, and binge eating.

Additionally, it was found out that there was a strong positive relationship between the WC mean score and the mean scores of the EC, SC, R, and BE subscales $(p<0.01)$. As the weight concern increased in young females, the levels of eating concern, shape concern, restraint, and binge eating also increased significantly.

A strong positive relationship was found between the mean EC score and the mean scores of the $\mathrm{SC}, \mathrm{R}$, and $\mathrm{BE}$ subscales $(\mathrm{p}<0.01)$. There was a significant increase in shape concern, restraint, and binge eating levels as the eating concern increased in young females.

A strong positive relationship was indicated between the mean SC score and the mean score of the $\mathrm{R}$ and $\mathrm{BE}$ subscales $(\mathrm{p}<0.01)$. As shape concern increased in young females, the level of restraint and binge eating also increased significantly.

It was found out that there was a strong positive relationship between the $\mathrm{R}$ mean score and the mean BE score $(\mathrm{p}<0.01)$. As restraint increased in young females and binge eating levels also increased significantly.

\begin{tabular}{|c|c|c|c|c|c|c|c|c|}
\hline & FCV-19S & SAAS & EDE-Q & WC & EC & SC & $\mathbf{R}$ & BE \\
\hline FCV-19S & 1 & & & & & & & \\
\hline SAAS & $\begin{array}{l}0.388^{* *} \\
\mathbf{0 . 0 0 0}\end{array}$ & 1 & & & & & & \\
\hline EDEQ & $\begin{array}{l}0.192^{\star *} \\
\mathbf{0 . 0 0 0}\end{array}$ & $\begin{array}{l}0.526^{* *} \\
\mathbf{0 . 0 0 0}\end{array}$ & 1 & & & & & \\
\hline WC & $\begin{array}{l}0.200^{\star *} \\
\mathbf{0 . 0 0 0}\end{array}$ & $\begin{array}{l}0.513^{\star \star} \\
\mathbf{0 . 0 0 0}\end{array}$ & $\begin{array}{l}0.927^{* *} \\
\mathbf{0 . 0 0 0} \\
\end{array}$ & 1 & & & & \\
\hline EC & $\begin{array}{l}0.192^{\star \star} \\
\mathbf{0 . 0 0 0}\end{array}$ & $\begin{array}{l}0.479^{\star *} \\
\mathbf{0 . 0 0 0}\end{array}$ & $\begin{array}{l}0.868^{* *} \\
\mathbf{0 . 0 0 0}\end{array}$ & $\begin{array}{l}0.758^{* *} \\
\mathbf{0 . 0 0 0}\end{array}$ & 1 & & & \\
\hline SC & $\begin{array}{l}0.172^{* *} \\
\mathbf{0 . 0 0 0}\end{array}$ & $\begin{array}{l}0.523^{* *} \\
\mathbf{0 . 0 0 0}\end{array}$ & $\begin{array}{l}0.949^{* *} \\
0.000\end{array}$ & $\begin{array}{l}0.876^{* *} \\
\mathbf{0 . 0 0 0}\end{array}$ & $\begin{array}{l}0.757^{* *} \\
\mathbf{0 . 0 0 0}\end{array}$ & 1 & & \\
\hline
\end{tabular}




\begin{tabular}{|c|c|c|c|c|c|c|c|c|}
\hline $\mathrm{R}$ & $\begin{array}{l}0.128^{\star *} \\
0.009\end{array}$ & $\begin{array}{l}0.341^{* *} \\
\mathbf{0 . 0 0 0}\end{array}$ & $\begin{array}{l}0.814^{* *} \\
\mathbf{0 . 0 0 0}\end{array}$ & $\begin{array}{l}0.656^{* *} \\
\mathbf{0 . 0 0 0}\end{array}$ & $\begin{array}{l}0.661^{* *} \\
\mathbf{0 . 0 0 0}\end{array}$ & $\begin{array}{l}0.659^{* *} \\
\mathbf{0 . 0 0 0}\end{array}$ & 1 & \\
\hline $\mathrm{BE}$ & $\begin{array}{l}0.129^{\star *} \\
\mathbf{0 . 0 0 9}\end{array}$ & $\begin{array}{l}0.209^{* *} \\
\mathbf{0 . 0 0 0}\end{array}$ & $\begin{array}{l}0.450^{* *} \\
\mathbf{0 . 0 0 0}\end{array}$ & $\begin{array}{l}0.428^{\star *} \\
\mathbf{0 . 0 0 0}\end{array}$ & $\begin{array}{l}0.433^{* *} \\
\mathbf{0 . 0 0 0}\end{array}$ & $\begin{array}{l}0.422^{* *} \\
\mathbf{0 . 0 0 0}\end{array}$ & $\begin{array}{l}0.328^{\star *} \\
\mathbf{0 . 0 0 0}\end{array}$ & 1 \\
\hline $\mathrm{M} \pm \mathrm{Sd}$ & $\begin{array}{l}18.51 \pm \\
6.86\end{array}$ & $\begin{array}{l}35.06 \pm \\
16.33\end{array}$ & $\begin{array}{l}9.01 \pm \\
7.46\end{array}$ & $\begin{array}{l}1.97 \pm \\
1.47\end{array}$ & $\begin{array}{l}0.91 \pm \\
1.21\end{array}$ & $\begin{array}{l}2.06 \pm \\
1.57\end{array}$ & $\begin{array}{l}1.02 \pm \\
1.43\end{array}$ & $\begin{array}{l}18.51 \pm \\
6.86\end{array}$ \\
\hline
\end{tabular}

${ }^{* *}$ Correlation is significant at the 0.01 level (2-tailed).FCV-19S, the Fear of COVID-19 Scale; SAAS, Social Appearance Anxiety Scale; EDE-Q, Eating Disorder Examination Questionnaire; R, restraint; EC, eating concern; SC, shape concern; WC, weight concern. BE, binge eating

In female students participating in the study, the fear of COVID-19 has a statistical significance in explaining social appearance anxiety $(15 \%)(\mathrm{p}<0.001$, Table 3$)$. Besides, COVID-19 fear in young females has statistical significance in explaining the eating disorder (3\%), weight concern (4\%), eating concern (3\%), shape concern $(3 \%)$, restraint $(1 \%)$, binge eating $(1 \%)(\mathrm{p}<0.01$, Table 3$)$.

Table 3. Multiple linear linear regression model of FCV-19S for SAAS, EDE - Q total score and subscales in participants $(n=416)$

\begin{tabular}{|l|l|c|c|c|c|c|c|}
\hline $\begin{array}{c}\text { Bağımlı } \\
\text { değișken }\end{array}$ & Değişkenler & Beta $^{\text {b }}$ & F & $\begin{array}{c}\text { d.f.(df1, } \\
\text { df2) }\end{array}$ & p-value & $\mathbf{R}^{2}$ & $t$ \\
\hline \multirow{7}{*}{ FCV-19S } & SAAS & 0.388 & 73.477 & 1414 & 0.000 & $\mathbf{0 . 1 5 1}$ & 8.572 \\
\cline { 2 - 8 } & EDE-Q & 0.192 & 15.797 & 1414 & 0.000 & 0.037 & 3.974 \\
\cline { 2 - 8 } & WC & 0.200 & 17.308 & 1414 & 0.000 & 0.040 & 4.160 \\
\cline { 2 - 8 } & EC & 0.192 & 15.846 & 1414 & 0.000 & 0.037 & 3.981 \\
\cline { 2 - 8 } & SC & 0.172 & 12.681 & 1414 & 0.000 & 0.030 & 3.561 \\
\cline { 2 - 8 } & R & 0.016 & 6.884 & 1414 & 0.009 & 0.016 & 2.624 \\
\hline & BE & 0.129 & 6.944 & 1414 & 0.009 & 0.017 & 2.635 \\
\hline
\end{tabular}

FCV-19S, the Fear of COVID-19 Scale; SAAS, Social Appearance Anxiety Scale; EDE-Q, Eating Disorder Examination Questionnaire; BE, binge eating; R, restraint; EC, eating concern; SC, shape concern; WC, weight concern.

\section{DISCUSSION}

The pandemic process with high levels of fear and stress negatively affected young people physically and mentally (Labrague et al., 2020; Wenjun et al., 2020).

According to the research results, it was determined that eating disorders (overeating) increased with the fear felt during the pandemic process. A study examining the eating behaviors of university students during the pandemic process found out that the stress that increased with the isolation process caused excessive eating (Flaudias et al., 2020). However, in a study, it was found that the risk of the eating disorder (binge eating) in women during the pandemic process was higher 
than in men (Flaudias et al., 2020). Additionally, according to the research results, it is seen that young females are also concerned about shape and weight, along with the fear of coronavirus. Similarly, it was stated in a study that the inability of young people to leave the house during the pandemic process and the disruption of their daily physical activities caused anxiety about weight and body shape (Rodgers et al., 2020). Especially in this process, education continues online at universities in Turkey, as well as at universities in many countries of the world. It is thought that the inadequacy of physical activity that occurs as a result of studying in front of the computer for a long time during the education process will cause weight gain and deterioration of body shape. Moreover, it is thought that these young people, almost all of whom are known to use social media and the internet, are more exposed to events such as news, comments, and videos that lead to concern, which results in fear and anxiety about their body shape (Lee, J. M., 2013; Turkish Statistical Institute, 2019). However, it was reported that sleep patterns and sleep problems occur with the coronavirus pandemic, and this situation changes food meals and causes meal skips (Dilber \& Dilber, 2020). The research findings concluded that a restrictive diet was observed in young females together with the fear of coronavirus. Based on this finding, a study showed that fear of coronavirus transmission increases the tendency to restrictive diets focused on increasing immunity (Rodgers et al., 2020). During the pandemic process in Turkey, there was a similar focus on specific food groups, and demand for foods that strengthen the immune system increased.

It was found in this study that social appearance anxiety increased as the fear of COVID-19 increased in young females. One of the factors that increase social appearance anxiety is the increased sense of loneliness (K1lıc M, 2015). Increasing isolation with the pandemic process brought loneliness along with it, causing a high rate of loneliness in young people (Labrague et al., 2020). Thus, in studies conducted during the pandemic process, it was shown that almost half of the youth between the ages of 18-24 experience high levels of loneliness (Bu et al., 2020; Labrague et al., 2021; Rauschenberg et al., 2020).

According to another study conducted during the pandemic, it was found that females have a higher risk of loneliness than males, and female students have a higher level of social loneliness than male students (Losada-Baltar et al., 2020; Salo et al., 2020; Labrague et al., 2020; Bu et al., 2020; Liu ve et al., 2020). It was reported that female students' higher social loneliness scores are due to higher participation in social activities, preferring more interpersonal commitment, and being more sensitive to interpersonal attachment than males (Barreto et al., 2021). The feeling of loneliness in young females who have become more vulnerable to social loneliness during the pandemic process also plays a triggering role in increasing social appearance anxiety. Moreover, in our study, it was found that eating disorder 
attitudes increased with fear was also correlated with social appearance anxiety. A study found out that people with positive eating attitudes also have positive social appearance anxiety (Cakaroglu et al., 2020). It is known that university years, which is one of the most important turning points in human life, are also important in terms of social appearance. During the pandemic process, eating attitudes change, and young females who experience eating disorders might experience more social appearance anxiety by experiencing more weight gain and anxiety about their physical appearance. In this case, it is predicted that it will negatively affect young females' social and academic lives. It is said that mental state assessment and counseling are of great importance in order not to negatively affect the psychology of young people and to increase their academic success (Tesfalem et al., 2019).

\section{CONCLUSION AND SUGGESTIONS}

In this study results are regarded as important due to the lack of other studies examining coronavirus fear, social appearance anxiety, and eating disorder. As a result of the study's findings, it was concluded that there is a significant relationship between COVID-19 fear level and social appearance anxiety and eating disorder, and especially the fear of COVID-19 has a significant effect on social appearance anxiety. It is thought that healthcare professionals should support young females better psychologically to make them less affected by the pandemic. Due to the high density of Turkey's youth population, it is indicated that young female university students need to be further empowered by providing the necessary training and consultancy.

\section{Acknowledge and explanations}

The authors thank to all the females who participated in this study.

This study was not funded.

Ethical approval (No: 2020/1251) was obtained from the Health Sciences Scientific Research and Publication Ethics Committee of the relevant university to conduct the study. Before the research was carried out, research permission (2020-1029T01-50-33) from the relevant Provincial Health Directorate of the Ministry of Health and institutional permission from the relevant faculties (Number of Documents: E.77240, E.80326) were received. Besides, before the data collection forms were filled, the participants were given the necessary explanations to protect their rights, and their verbal consent was obtained with the "Informed Consent Form." 


\title{
Conflict of interest
}

\section{The author declares no conflict of interest.}

\section{Authorship Contributions}

\author{
Study design, Data collection, Data analysis, Drafting of the article and critical \\ revisions of the article were made by Hacer Unver.
}

\section{REFERENCES}

Ahorsu, D. K., Lin, C. Y., Imani, V., Saffari, M., Griffiths, M. D., \& Pakpour, A. H. (2020) The Fear of CovID- 19 Scale: development and initial validation. International Journal of Mental Health and Addiction, 1. https://doi. org/10.1007/s11469-020-00270-8

Akbas, Ö. Z., \& Dursun, C. (2020). Mothers interpolating publıc space into private space during the coronavirus (covid-19) pandemic. Eurasian Journal of Researches in Social and Economics (EJRSE) ISSN:2148-9963, 7(5); $78-94$.

Akdevelioglu, Y, Yorusun, T . (2019). Investigation of some factors related to eating attitudes and behaviors of university students. Gazi Journal of Health Sciences, 4(1),19-28. https://dergipark.org.tr/tr/pub/gsbdergi/ issue/46054/579500

Barreto, M., Victor, C., Hammond, C., Eccles, A., Richins, M. T., \& Qualter, P. (2021). Loneliness around the world: Age, gender, and cultural differences in loneliness. Personality and Individual Differences, 169(January 2020), 110066. https://doi.org/10.1016/j.paid.2020.110066

Bu, F., Steptoe, A., \& Fancourt, D. (2020). Loneliness during a strict lockdown: Trajectories and predictors during the COVID-19 pandemic in 38,217 United Kingdom adults. Social Science and Medicine, 265. https://doi. org/10.1016/j.socscimed.2020.113521.

Cakaroglu, D., Omur, E. H., \& Arslan, C. (2020). Examination of Eating Attitude Eating Awareness and Social Appearance Anxiety of University Students (Samples of Province of Siirt). Physical Education and Sport Sciences Journal, 14(1), 1-12.

Craig A. Harper \& Liam P. Satchell \& Dean Fido \& Robert D. Latzman. (2020). Functional Fear Predicts Public Health Compliance in the COVID-19 Pandemic. International Journal of Mental Health and Addiction. https://doi. org/10.15446/revfacmed.v68n1.86482.

Dilber, A., \& Dilber, F. (2020). The Effect of Coronavirus ( COVID-19) Disease on the Nutritional Habits of Individuals : The Case Karaman Province. Journal of Tourism and Gastronomy Studies, 8(3), 2144-2162. https://doi. org/10.21325/jotags.2020.653.

Doğan T. (2010). Adaptation of the social appearance anxiety scale (SAAS) to Turkish: a validity and reliability study. Hacettepe University Journal of Education 39: 151-159.

Ercan, F. B. \& O. K. \& H. (2020). Fear of COVID-19 and Positivity: Mediating Role of Intolerance of Uncertainty, Depression, Anxiety, and Stress. https://covid19.who.int/

Eksi H., Arıcan T., Yaman G. (2016). The Perfectionizm and Social Appearance Anxiety as Being The Prediction of Risky Behavior on Vocational High School Students. Journal of Ahi Evran University Kirşehir Faculty of Education. 17(2), 527-545.

Fairburn, C. G., Cooper, Z., \& O'Connor, M. (1993). The eating disorder examination. International Journal of Eating Disorders, 6, 1-8.

,Flaudias, V., Iceta, S., Zerhouni, O., Rodgers, R. F., Billieux, J., Llorca, P. M., Boudesseul, J., Chazeron, I. D. E., Romo, L., Maurage, P., Samalin, L., Begue, L., Naassila, M., Brousse, G., \& Guillaume, S. (2020). COVID-19 pandemic lockdown and problematic eating behaviors in a student population. Journal of Behavioral Addictions, 9(3), 826-835. https://doi.org/10.1556/2006.2020.00053

Hart, T. A., Flora, D. B., Palyo, S. A., Fresco, D. M., Holle, C., \& Heimberg, R. G. (2008). Development and examination of the social appearance anxiety scale. Assessment, 15(1), 48-59. 
Jiao, W. Y., Wang, L. N., Liu, J., Fang, S. F., Jiao, F. Y., Pettoello-Mantovani, M., \& Somekh, E. (2020). Behavioral and Emotional Disorders in Children during the COVID-19 Epidemic. Journal of Pediatrics, 221, 264-266.e1. https:// doi.org/10.1016/j.jpeds.2020.03.013

Kara A. (2016). Examining the relationships between social appearance anxiety and shyness. Individual and Society. 6(11), 95-106.

Kartal A, Y, Kaykısız, E. (2020) Investigation of the relationship between eating behaviors and premenstrual syndrome symptoms of midwifery students in the covid-19 outbreak. Medical Sciences, 15(4):133-143, DOI: 10.12739/NWSA.2020.15.4.1B0097.

Kılıc, M. (2015). Üniversite Öğrencilerinin Sosyal Görünüş Kaygilari Ile Benlik Saygilari Ve Yalnizlik Düzeyleri Arasindailişkinin Incelenmesi.

Labrague, L. J., De los Santos, J. A. A., \& Falguera, C. (2020). Social and emotional loneliness among college students during the COVID-19 pandemic: the predictive role of coping behaviours, social support, and personal resilience. Preprint, August, 1-15. https://doi.org/10.1111/ppc.12721

Lee, J. M. (2013). Validity of consumer-based physical activity monitors and calibration of smartphone for prediction of physical activity energy expenditure.

Oruçlular, Yasemin. The Mediator Role of Body Perception on the Relationship Between Autonomous-Related Self Constructs and Eating Attitude, Master's Thesis, Ankara, 2013, Hacettepe University Institute of Social Sciences, Department of Psychology, Division of Clinical Psychology, Ankara.

Rauschenberg, C., Schick, A., Goetzl, C., Röhr, S., Riedel-Heller, S., Koppe, G., Durstewitz, D., Krumm, S., \& Reininghaus, U. (2020). Social isolation, mental health, and use of digital interventions in youth during the COVID-19 pandemic: a nationally representative survey. PsyArXiv, 1-28. https://doi.org/10.31234/osf.io/v64hf

Republic of Turkey Ministry of Health. (2020b). COVID-19 (SARS-CoV-2 Infection) Guidelines. https://covid19bilgi. saglik.gov.tr/depo/rehberler/COVID-19_Rehberi.pdf (Access Date: 02 May 2020).

Rodgers, R. F., Lombardo, C., Cerolini, S., Franko, D. L., Omori, M., Fuller-Tyszkiewicz, M., Linardon, J., Courtet, P., \& Guillaume, S. (2020). The impact of the CoVID-19 pandemic on eating disorder risk and symptoms. International Journal of Eating Disorders, 53(7), 1166-1170. https://doi.org/10.1002/eat.23318

Sarıcam, H., Erguvan, F. M., Akın, A., \& Akça, M. Ş. (2014). Turkish form of the intolerance to uncertainty scale: a study of validity and reliability. Route Educational and Social Science Journal, 1(3):148-57.

Satici, B., Gocet-Tekin, E., Deniz, M. E., \& Satici, S. A. (2020). Adaptation of the Fear of COVID-19 Scale: Its association with psychological distress and life satisfaction in Turkey. International Journal of Mental Health and Addiction. doi: 10.10.1007/s11469-020-00294-0

Sarı, S., \& Dağ, l. (2009). Problem solving style, hopelessness, helplessness and haplessness as the predictors of psychopathology assessed by MMPI-2. Anatolian Journal of Psychiatry, 10, 261-70.

Serin, Y. ve Şanlıer, N., (2018). Emotional eating, factors affecting food intake and basic nursing approaches. J Psychiatric Nurs 2018; 9(2):135-146.

Simsir Z., Seki T., Dilmac B. (2019) Gender Differences in Social Appearance Anxiety: A Meta-Analysis Study. International Journal of Society Researches. 10(17), 615-637.

Steinberg, J. R., Tschann, J. M., Furgerson, D., \& Harper, C. C. (2016). Social Science \& Medicine Psychosocial factors and pre-abortion psychological health : The significance of stigma. Social Science \& Medicine, 150, 67-75. https://doi.org/10.1016/j.socscimed.2015.12.007.

Taylor, S., Landry, C. A., Paluszek, M. M., Fergus, T. A., McKay, D., \& Asmundson, G. J. G. (2020). Development and initial validation of the COVID Stress Scales. Journal of Anxiety Disorders, 72(May), 102232. https://doi. org/10.1016/j.janxdis.2020.102232

Tesfalem Teshome Tessema, Temesgen Abdi Gebremariam, Etaferahu Alemayehu Abebe, Ribka Dinku Gebre. The Prevalence and Factors Associated with Mental Distress among College Students in Southern Ethiopia : A CrossSectional Study Ethiop J Health Sci. 2019;29(3):353. doi:http://dx.doi.org/10.4314/ ejhs.v29i3.

Turkey Statistical Institution (2019). Household information technologies usage survey. http://www.tuik.gov.tr.

Wenjun, C., Ziwei, F., Guoqiang, H., Mei, H., Xinrong, X., Jiaxin, D., \& Jianzhong, Z. (2020). The psychological impact of the COVID-19 epidemic on college students in China. Psychiatry Research, 287(March 20, 2020), 1-5.doi. org/10.1016/j.psychres.2020.112934.

WHO. (2020b). Q\&A on coronaviruses (COVID-19). https://www.who.int/emergencies/ diseases/novelcoronavirus-2019/question-and-answers-hub/q-a-detail/q-a-coronaviruses (Erişim Tarihi: 3 Mayıs 2020). 
Yucel, B., Polat, A., Ikiz, T., Dusgor, B. P., Elif Yavuz, A. ve Sertel Berk, O. (2011). The Turkish version of the eating disorder examination questionnaire: reliability and validity in adolescents. European Eating Disorders Review, 19(6), 509-511.doi:10.1002/erv.1104

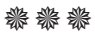

